\title{
Forecasting Dual-Gap for Pakistan
}

\section{Salman Ahmad*}

\section{Introduction}

Economic growth requires investment goods that may either be provided domestically or be purchased from abroad. Domestic provision requires saving; the foreign provision requires foreign exchange. If some investment goods for growth can only be provided from abroad, there is always a minimum amount of foreign exchange required to sustain the growth process. The distinctive contribution of the dual-gap analysis to development theory is that if foreign exchange is the dominant constraint it points to the dual role of foreign borrowing in supplementing not only deficient domestic saving but also foreign exchange. The Dual-gap theory thus performs the valuable service of emphasising the role of imports and foreign exchange in the development process. It synthesises traditional and more modern views concerning aid, trade and development. On the one hand, it embraces the traditional view of foreign assistance as merely a boost to domestic saving; on the other hand, it takes a more modern view that many goods necessary for growth cannot be produced by the developing countries themselves and must therefore be imported with the aid of foreign assistance. Indeed, if foreign exchange is the dominant constraint, it can be argued that dual-gap analysis also presents a more relevant theory of trade for developing countries which justifies protection and import substitution. If growth is constrained by a lack of foreign exchange, free trade cannot guarantee simultaneous internal and external equilibrium, and the gains from trade may be offset by the underutilisation of domestic resources.

\section{The Theoretical Framework}

In the Harrod model of growth, the relation between growth and saving is given by the incremental capital -output ratio (c), i.e. $\mathrm{g}=\mathrm{s} / \mathrm{c}$, where $g$ is the growth rate and $s$ is the saving ratio. Likewise, the growth rate can be expressed as the product of the incremental output-import ratio $(\Delta \mathrm{Y} / \mathrm{M}=\mathrm{m})$ and the ratio of investment goods imports to income $(\mathrm{M} / \mathrm{Y}=\mathrm{i})$, i.e. $\mathrm{g}=\mathrm{im}$ '.

If there is a lack of substitutability between domestic and foreign resources, growth will be constrained by whichever factor is the most limiting- domestic savings or foreign exchange. Suppose, for example, that

\footnotetext{
* The author is Professor of Economics at The Lahore School of Economics.
} 
the growth rate permitted by domestic saving is less than the growth rate permitted by the availability of foreign exchange, growth would be "savings -limited" and if the constraint is not lifted, a proportion of foreign exchange will go unused. Contrawise, growth will be "foreign-exchange limited". In both cases, there will be resource waste as long as one resource constraint is dominant. If foreign exchange is the dominant constraint ways must be found of using unused domestic resources to earn more foreign exchange. If domestic saving is the dominant constraint ways must be found of using foreign exchange to augment domestic saving.

Suppose, a country sets a target rate of growth, r. The required savings ratio $\mathrm{s}^{*}$ to achieve the target is $\mathrm{s}^{*}=\mathrm{r}$, and the required import ratio $i^{*}=r / m^{\prime}$. If domestic saving is calculated to be less than the level required to achieve the target rate of growth, there is said to exist an investment -saving gap equal at time $t$, to

$$
\mathrm{I}-\mathrm{S}=\mathrm{s}^{*} \mathrm{Y}=(\mathrm{r} \mathrm{c}) \mathrm{Y}-\mathrm{sY}
$$

Similarly, if minimum import requirements to achieve the growth target are calculated to be greater than the maximum level of export earnings available for investment purposes, there is said to exist an importexport gap equal at time $t$, to

$$
\mathrm{M}-\mathrm{X}=\mathrm{I}^{*} \mathrm{Y}-\mathrm{iY}=\left(\mathrm{r} / \mathrm{m}^{\prime}\right) \mathrm{Y}-\mathrm{iY}
$$

where $i$ is the ratio of imports to output which is permitted by export earnings. If the target growth rate is to be achieved, foreign capital flows must fill the largest of the two gaps. The two gaps are not additive. If the import-export gap is the larger, then foreign borrowing to fill it will also fill the investment-saving gap. If the investment-saving gap is the larger, foreign borrowing to fill it will obviously cover the smaller foreign exchange gap.

To start with, we assume that the I -S gap is the larger of the two gaps, so that foreign borrowing must be sufficient to meet the shortfall of domestic saving below the level necessary to achieve the target rate of growth. We want to consider the size of the initial gap that must be filled by foreign borrowing and the determinants of the size of the gap to be filled in future years by foreign assistance. If the gap is to narrow, and foreign borrowing is to be terminated, the presumption must be that additional increments to saving out of the increases in national income generated are greater than the increments of investment. For any target rate of growth, $r$, the required foreign assistance in the base year $(\mathrm{Fo})$ is:

$$
\text { Fo }=\text { Io }- \text { So }=\text { Yo } \mathrm{cr}-\text { Yo s }
$$




$$
=Y_{0}(c r-s)
$$

where Io is investment in the base period, So is the savings in the base period, Yo is income in the base period, $s$ is the average savings ratio.

If the $\mathrm{M}-\mathrm{X}$ gap is the larger of the two gaps, the foreign assistance required to cover the foreign exchange gap in the base year is:

$$
\begin{aligned}
\text { Fo } & =\text { Mo }-X O=\text { Yom }- \text { Yo }- \text { Yox } \\
& =\text { Yo }(m-x)
\end{aligned}
$$

where Mo is imports in the base period, Xo is exports in the base period, Yo is income in the base period, $\mathrm{m}$ is the average import coefficient, and $\mathrm{x}$ is the average export coefficient.

\section{Estimation and Empirical Findings}

\section{a) Investment requirements}

The calculation of investment requirements for growth first requires an estimate of the incremental capital-output ratio. Empirical evidence shows the COR has a sort of parabolic relationship with the growth of the economy. As development proceeds, the COR first tends to rise but when development gains momentum, it starts to decline and finally becomes stationary. V.V. Bhatt (1954) made a comparative study of industries in both developed and underdeveloped countries in the early fifties and did not find any marked difference in their respective COR. With respect to the probable size of the COR in underdeveloped countries like Pakistan, the consensus is at 3.5 as used by us. We have taken the average of Pakistan's growth rates of the decade of $90 \mathrm{~s}$ as the target GDP growth rate which comes to 4.92 per cent. So the investment requirement at time $t$ is given by

$$
\begin{aligned}
& I=\text { COR. G. Yt } \\
& I=(3.5)(0.049) Y t .
\end{aligned}
$$

\section{b) Savings}

Adopting the simple Keynesian savings function, and regressing the level of domestic savings on gross national product over the period 1990-91 to 2000-01 gave the following result (standard error in brackets):

$$
\mathrm{S}=7105+0.076 \mathrm{Y} \quad\left(\mathrm{R}^{2}=0.36\right)
$$


106 The Lahore Journal of Economics, Vol.6, No.2

where the units of measurement are in millions of rupees. The correlation coefficient is not so high, and a high intercept shows that average and marginal propensities to save are not equal over the period. We employ this function to forecast savings for the period 2001-02 to 2006-07. Thus, given the target level of income, Yt $(\mathrm{t}=1$ to 5$)$, from applying the target rate of growth to the base year level of income Yo, the 1 - S gap can be estimated for each year in the future. The results are shown in the Table. All values are in rupees at constant factor cost (1980-81) prices.

\section{c) Import Requirement}

Adopting the simple linear import function, and regressing the level of imports on gross national product over the period 1990-91 to 2000-01 gave the following result (standard error in brackets):

$$
\mathrm{M}=-501946+1.54 \mathrm{Y} \quad\left(\mathrm{R}^{2}=0.89\right)
$$

where the units of measurement are in millions of rupees. The correlation coefficient is extremely high, and a high intercept shows that average and marginal propensities of imports are not equal over the period. We employ this function to forecast imports for the period 2001-02 to 20062007. Thus, given the target level of income, $\mathrm{Yt}(\mathrm{t}=1$ to 5), from applying the target rate of growth to the base year level of income Yo, the $\mathrm{M}-\mathrm{X}$ gap can be estimated for each year in the future. The results are shown in the Table. All values are in rupees at constant factor cost (198081) prices.

\section{d) Exports}

A simple exponential trend rate of growth of exports is assumed. The function is

$$
\mathrm{X}=\mathrm{Xo} \mathrm{e}^{\mathrm{bt}}
$$

The estimated trend equation is

$$
\log \mathrm{X}=4.333+.068 \mathrm{t},\left(\mathrm{R}^{2}=0.98\right)
$$


In estimating the export-import gap, therefore, an export growth rate of 6.8 per cent is assumed. The calculated import-export gap is also shown in the Table.

Table: Estimates of the Savings-Investment and Export-Import gaps, 2001-02 - 2005-06 (Rs. Million) (Base Year)

\begin{tabular}{lrrrrrr}
\hline & 2000-01 & 2001-02 & 2002-03 & 2003-04 & 2004-05 & 2005-06 \\
\hline GDP & 666115.0 & 698887.9 & 723273.1 & 769350.2 & 807202.2 & 846916.9 \\
Savings & 57729.7 & 60220.5 & 62833.8 & 65575.6 & 68452.4 & 71470.7 \\
Investment & 114705.0 & 120348.5 & 126269.6 & 132482.1 & 139000.2 & 145839.0 \\
I - S gap & 56975.3 & 60128.0 & 63435.8 & 66906.5 & 70547.8 & 74368.3 \\
Exports & 382818.2 & 408849.8 & 436651.6 & 466343.9 & 498055.3 & 531922.7 \\
Imports & 523871.1 & 574341.3 & 627294.6 & 682853.3 & 741145.4 & 802305.5 \\
M - X gap & 141052.9 & 165491.5 & 190643.0 & 216509.4 & 243090.1 & 270382.8 \\
\hline
\end{tabular}

The results show that the import-export gap is dominant. So for the target rate of growth to be achieved, there would have to be foreign borrowing each year to fill the bigger of the two gaps. 
108 The Lahore Journal of Economics, Vol.6, No.2

\section{References}

Adelman, I and Chenery, H. "Foreign Aid and Economic Development": the case of Greece” Review of Economics and Statistics, Feb., 1966.

Bhatt, V.V. "Capital-Output ratios of Certain Industries: a comparative study of certain countries" in Review of Economics and Statistics, August, 1954.

Chenery, H. and Bruno, M. "Development Alternatives in an Open Economy: the case of Israel”, Economic Journal, March, 1962.

Chenery, H. and MacEwan, A. "Optimal Patterns of Growth and Aid: the case of Pakistan” Pakistan Development Review, Summer, 1966.

Chenery, H. and Strout, A. "Foreign Assistance and Economic Development", American Economic Review, September, 1966.

Chenery, H. and Eckstein, P. "Development Alternatives for Latin America", Journal of Political Economy, August, 1970.

E1-Shibly, M. and Thirlwall, A.P. "Dual Gap Analysis for the Sudan”, World Development, Feb., 1981.

Government of Pakistan, Economic Survey (2000-2001), Ministry of Finance, Islamabad.

Harrod, R.F., “An essay in dynamic theory”, Economic Journal, March, 1939 . 